\title{
ENHANCEMENT OF NUTRIENTS UPTAKE BY LUPIN (Lupinus Albus L.) PLANT INOCULATED WITH BACTERIA AND IRRIGATED WITH SALINE WATER \\ El-Hadidi, E. M. ${ }^{1}$; S. M. Msoliman'; Y.G.M.Galal ${ }^{2}$ and M.A.E. Soliman ${ }^{1}$ \\ 1 Department of Soil Science, Faculty of Agriculture, Mansoura University \\ 2 Atomic Energy Authority, Nuclear Research Center, Soil \& Water Research department, Abou-Zaabl, 13759 Egypt
}

\begin{abstract}
A pot experiment was carried out under greenhouse conditions to trace the effect of water salinity and bacterial inoculation on growth parameters and nutrient uptake by lupin (Lupinus Albus L.). Experimental results showed that the growth parameters i.e. shoot and root dry weight and nutrient uptake by different plant parts were frequently affected by the effective factors. Dry matter yield of shoots was gradually increased with increasing water salinity levels. This phenomenon was more pronounced with $3 \mathrm{dS} \mathrm{m}^{-1}$ rather than $6 \mathrm{dS} \mathrm{m}^{-1}$ water salinity level. This holds true with all inoculation treatments. Similar trend was noticed with root dry matter yield but only in case of uninoculated treatment while the other inoculants reflected decline trend with increasing water salinity levels up to $6 \mathrm{dS} \mathrm{m}^{-1}$. N uptake by shoots was positively affected by water salinity levels under bacterial inoculation except the dual treatments where $\mathrm{N}$ uptake tended to decrease with increasing water salinity levels. $\mathrm{N}$ uptake by roots was severely affected by increasing water salinity levels as compared to fresh water treatment. $\mathrm{N}$ uptake by shoots was enhanced by inoculation under different water salinity levels as compared to the uninoculated treatment. Nitrogen uptake by roots was dramatically affected by inoculation. It was only increased by inoculation when plants were irrigated with fresh water.

Acquisition of $\mathrm{K}$ by shoot and roots of lupin plants was frequently affected by either water salinity or bacterial inoculation. Concerning the effect of bacterial inoculation, in general, the values of K-uptake by shoots was increased due to inoculation treatments. Opposite direction was noticed with root-K where it decreased with inoculation treatments comparable to uninoculated one.

Sodium uptake by shoot and root was positively affected by either increasing water salinity levels or bacterial inoculation. It is obvious that $\mathrm{Na}$ absorption was gradually increased with increasing water salinity levels up to $6 \mathrm{dS} \mathrm{m}^{-1}$. This holds true under all inoculation treatments. Also, the results of both shoots and roots were nearly closed to each other. Generally, the highest values of $\mathrm{Na}$ content in shoots or roots were recorded with $6 \mathrm{dS} \mathrm{m}^{-1}$ water salinity level.
\end{abstract}

Keywords: Bacterial inoculation, Lupin, Nutrient uptake, Sandy soil, Water salinity

\section{INTRODUCTION}

The increased demand of freshwater resources is a global concern, but for the Mediterranean region and particularly the arid and semi-arid region, it becomes a serious challenge (Hamdy 2005).

Plant needs for water and nutrients are interdependent. Water is not only required for the growth of plants but is also the medium through which 
nutrients are transported to the roots and absorbed by them. A good water supply improves the nutritional status of crops, and an adequate nutrient supply saves water. A crop can suffer from several types of stresses during its growth. These may be caused by soil, moisture, temperature, salinity, nutrient deficiencies or toxicities, pests and diseases. The response of crops to various stresses is often affected by their nutrient status. Optimizing plant nutrition can enable the crop to withstand such stresses and emerge with minimum loss of yield (Vlek and Vielhauer 1994).

In saline and alkaline soils, exchangeable $\mathrm{Na}$ is present in very large amounts compared with exchangeable $\mathrm{Ca}$ and $\mathrm{K}$. $\mathrm{Na}$ is not an essential plant nutrient. There are indications of an association between the tolerance of a crop or a crop variety to salinity and its $\mathrm{K}$ status. Salt-tolerant crops are generally found to contain more $K$ than crops susceptible to salinity. It has been shown that crop varieties that can absorb $\mathrm{K}$ in preference over $\mathrm{Na}$ are relatively more tolerant to salinity and alkalinity (Rana, 1986). In tomatoes, the $\mathrm{K}^{+} / \mathrm{Na}^{+}$selectivity ratio was also higher in the salt-tolerant variety than in a non-tolerant variety (Kant and Kafkafi, 2002). These results suggest that maintaining adequate levels of $\mathrm{K}$ and $\mathrm{K}^{+} / \mathrm{Na}^{+}$ratios in plant cells is essential for normal growth under saline conditions.

Bacteria of the genus Rhizobium are able to establish symbiotic relationships with many leguminous plants, as a result of which the nitrogen gas $\left(\mathrm{N}_{2}\right)$ of the air is "fixed" or converted to ammonium ions that can be utilized by plants. Inoculation with Rhizobium is recommended for legumes (pulses, oilseeds and forages). On average, yield response to Rhizobium inoculation varies from 10 to 60 percent depending on the soil-climate situation and efficiency of the strain (Roy et al. 2006). Salinity is one of the most important stresses affecting legume development and symbiotic $\mathrm{N}_{2}$ fixation (Zahran, 1999), being rhizobial-legume symbiosis, including nodule development and nitrogen fixation more sensitive to salt than either symbiotic partner by itself.

Lupine as a leguminous crop is grown well even on poor soils, which gives to Lupine a distinct advantage. Application of both single and multistrains of Rhizobia has a positive effect on nodulation of Lupine cultivars cultivated on poor sandy soils (Raza et al. 2000). They also concluded that considerable genotypes-rhizobial isolate interactions should be borne in mind, therefore, continuous monitoring of symbiotic compatibility of lupine and Rhizobium isolates is important Lupine-Rhizobium specificity and effects on enhancement of dry matter accumulation and $\mathrm{N}$ nutrition was defected (Howieson et al, 1994).

Azospirillum, a spiral-shaped $\mathrm{N}$-fixing bacteria, is widely distributed in soils and grass roots. Major species of Azospirillum are Azospirillum brasilense and Azospirillum lipoferum. It can fix $20-50 \mathrm{~kg} \mathrm{~N} / \mathrm{ha}$ in association with roots. It also produces hormones such as indole acetic acid (IAA), gibberellic acid (GA), cytokinins and vitamins. Free-living nitrogen $(\mathrm{N})$ fixation can be important for sustainable soil fertility, particularly in extensively managed soils with low abundance of leguminous plant species. The activity of free-living $\mathrm{N}_{2}$-fixers is more important in soils having low active microbial biomass and low $\mathrm{N}$-mineralization rates (Patra et al. 2006). 
These bacteria are interesting because, firstly, they can assimilate atmospheric nitrogen and in this way contribute to nitrogen nutrition of plants; secondly, they promote absorption of nutritive substances by the plant and create beneficial conditions for the protection of the root system from pathogenic bacteria, and thirdly, they participate in the regulation of the flow of nutrients and the production of auxin phytohormones (Steenhoudt and Vanderleyden, 2000). Saatovich (2006) examined the tolerance of Azospirillum brasilense and Azospirillum lipoferum to salt stress and he found that Azospirilli strains displayed a varying salt resistance on potato medium containing a range of $\mathrm{NaCl}$ concentrations from 100 to $800 \mathrm{mM}$. The decrease in the nitrogen-fixing activity of azospirilli was detected starting from $200 \mathrm{mM} \mathrm{NaCl}$.

Bashan et al. (1990) showed that the capacity of Azospirillum brasilense to enhance the accumulation of $\mathrm{K}^{+}, \mathrm{P}, \mathrm{Ca}^{2+}, \mathrm{Mg}^{2+}, \mathrm{S}, \mathrm{Na}^{+}, \mathrm{Mn}^{2+}, \mathrm{Fe}^{2+}, \mathrm{B}$, $\mathrm{Cu}^{2+}$, and $\mathrm{Zn}^{2+}$ in inoculated wheat and soybean plants was evaluated by using two different analytical methods with five $A$. brasilense strains originating from four distinct geographical regions. The degree of plant response to inoculation varied among the different strains of $A$. brasilense. All strains were capable of colonizing roots, but the best root colonizer, Pseudomonas sp., had no effect on plant growth. They suggested that, although $A$. brasilense strains are capable of changing the mineral balance and content of plants, it is unlikely that this ability is a general mechanism responsible for plant improvement by $A$. brasilense. Similar findings were reported by Galal and Ali (2004, also see the references there in); Galal (1997).

The objective of this work is to examine the response of lupin plant to bacterial inoculation under water salinity stress with special emphasis on growth parameters as well as nutrient availability to the host plant.

\section{MATERIALS AND METHODS}

A pot experiment was installed under greenhouse conditions using lupin (Lupinus Albus L. Giza 2) as a tested crop. Light texture sandy soil collected from the area of Inshas that belonging to Sharkeya Governorate. Some physical and chemical characteristics of soil samples are presented in Table 1. Soil samples were packed in plastic pots at rate of $5 \mathrm{~kg} \mathrm{pot}^{-1}$. Soil was prepared and mixed with base doses of $50 \mathrm{~kg} \mathrm{~K} \mathrm{fed}^{-1}$ as potassium sulfate and $150 \mathrm{~kg} \mathrm{P} \mathrm{fed}^{-1}$ as superphosphate before planting.

All pots were seeded with lupin at rate of 8 seeds pot $^{-1}$. After emergency the lupin seedlings were thinned to 5 seedling pot $^{-1}$. Thirty-six pots were arranged in greenhouse according to the completely randomized block design. Seeds of lupines were coated with peat-based carrier of Rhizobium leguminosarum as described by Vincent (1970). While Azospirillum brasilense inoculum was added as liquid broth into the holes of each seedling $\left(1 \mathrm{ml} \mathrm{hole}{ }^{-1}\right)$. Uninoculated treatment was also included. After emergency, the 
labeled ${ }^{15} \mathrm{~N}$-fertilizer $\left({ }^{15} \mathrm{NH}_{2} \mathrm{SO}_{4}\right.$ with $2 \%$ atom excess), was applied at rate of 20 units of $\mathrm{N}$ for both inoculated and uninoculated plants.

Fertilizer was diluted in proper volume of bidistilled water according to calculated amounts of labeled $\mathrm{N}$ fertilizer needed for the experiments, then mixed thoroughly and applied carefully to the surface of each pot. The experimental treatments were as following:

1- Uninoculated

2- Inoculated with Azospirillum brasilense

3- Inoculated with Rhizobium leguminosarum

4- Inoculated with Azospirillum brasilense+ Rhizobium leguminosarum

\section{Irrigation water}

All of these treatments were irrigated with F.W., 3 and $6 \mathrm{dS} \mathrm{m}^{-1}$. Saline irrigation water prepared by mixing sea water $\left(35.5 \mathrm{dS} \mathrm{m}^{-1}\right)$ with fresh water, according to the following equation, to give the following salinity levels:

1- $50 \mathrm{ml}$ of sea water $+1130 \mathrm{ml}$ of fresh water to obtain $3 \mathrm{dS} \mathrm{m}-1$ salinity level.

2- $100 \mathrm{ml}$ of sea water $+930 \mathrm{ml}$ of fresh water to obtain $6 \mathrm{dS} \mathrm{m}-1$ salinity level.

3- Fresh water was also included as control treatment.

The equation of Ayers and Westcot (1989) for calculating the irrigation water EC.

$$
E C_{\text {s.w }} \times \mathrm{EC}_{\mathrm{F} . \mathrm{w}}
$$

$\left[\mathrm{EC}_{\text {s.w }}{ }^{*}\right.$ proportion used $]+\left[\mathrm{EC}_{\mathrm{F} . \mathrm{w}}{ }^{*}\right.$ proportion used $]=\mathrm{EC}_{\text {mix.water }}$

At harvest time, the plants were picked up from the soil, carefully washed with tape water then separated into shoots and roots. Both organs were oven dried at 70 OC for $48 \mathrm{~h}$, then the dry weight of shoots and roots were recorded. The plant parts were subjected to chemical analyses.

\section{Bacterial Inoculants}

Rhizobium leguminosarum var viceae and Azospirillum brasilense NO 40 were provided by culture collection unit of biofertilizers production, Agricultural Research Center (ARC). It practically adapted to saline soil conditions.

Rhizobium leguminosarum var viceae culture was maintained and multiplied on yeast extract mannitol medium (YEM) agar slops (Vincent, 1970). Azospirillum brasilense was multiplied on $\mathrm{NFb}$ liquid medium containing $0.1 \% \mathrm{NH}_{4} \mathrm{Cl}$ (Döbereiner and Day, 1976) 
Table 1. Some physical and chemical properties of the experimental soil samples.

\begin{tabular}{|c|c|}
\hline Property & Value \\
\hline \multicolumn{2}{|l|}{ Soil texture (\%) } \\
\hline Sand & 88.5 \\
\hline Clay & 8.8 \\
\hline Silt & 2.7 \\
\hline $\mathrm{pH}\left(1: 2.5 \mathrm{H}_{2} \mathrm{O}\right)$ & 7.8 \\
\hline $\mathrm{EC}\left(\mathrm{dS} \mathrm{m}^{-1}\right)$ & 0.35 \\
\hline Organic matter (\%) & 0.03 \\
\hline Total N (\%) & 0.08 \\
\hline Available $\mathrm{P}$ ( $\mathrm{mg} \mathrm{kg}^{-1}$ soil) & 2.1 \\
\hline \multirow{2}{*}{\multicolumn{2}{|c|}{ Cations (meq $100 \mathrm{~g}^{-1}$ soil) }} \\
\hline & \\
\hline $\mathrm{Na}^{+}$ & 0.32 \\
\hline $\mathrm{K}^{+}$ & 0.09 \\
\hline $\mathrm{Ca}^{++}$ & 1.2 \\
\hline $\mathrm{Mg}^{++}$ & 1.0 \\
\hline \multicolumn{2}{|l|}{ Anions (meq $100 \mathrm{~g}^{-1}$ soil) } \\
\hline $\mathrm{HCO}_{3}^{-}$ & 0.88 \\
\hline $\mathrm{CO}_{3}{ }^{2-}$ & 0.00 \\
\hline $\mathrm{SO}_{4}^{2-}$ & 0.53 \\
\hline $\mathrm{Cl}^{-}$ & 1.20 \\
\hline
\end{tabular}

The chemical analysis of saline water used in the present study is listed in Table (2).

Table 2. Chemical analysis of saline water used for irrigation.

\begin{tabular}{l|l}
\hline Property & Value \\
\hline $\mathrm{pH}$ & 8.4 \\
$\mathrm{EC}$ & $35.5 \mathrm{dS} \mathrm{m}^{-1}$ \\
$\mathrm{Cl}^{-}$ & $336.7 \mathrm{meq} \mathrm{l}^{-1}$ \\
$\mathrm{Mg}^{++}$ & $147.4 \mathrm{meq} \mathrm{I}^{-1}$ \\
$\mathrm{Ca}^{++}$ & $22.1 \mathrm{meq} \mathrm{l}^{-1}$ \\
$\mathrm{~B}$ & $4.35 \mathrm{meq} \mathrm{l}^{-1}$ \\
$\mathrm{HCO}_{3}^{-}$ & $3.4 \mathrm{meq} \mathrm{l}^{-1}$ \\
\hline
\end{tabular}

Determinations

- All chemical analysis of soil samples were determined according to Page et al. (1982).

- All chemical analysis of plant samples were determined according to ICARDA Manual (Ryan et al., 2001) and Hamdy (2005).

\section{Statistical Analysis}

Analysis of variance (ANOVA) for the final data obtained in the present study was carried out and Least Significant Differences (LSD) among the means of various treatments followed by Duncan's multiple range test was also applied at $5 \%$ level according to SAS, (1987). 


\section{RESULTS AND DISCUSION}

\section{Dry matter yield}

Experimental data presented in Table (3) indicated that the dry matter yield of shoot and root was significantly affected by either inoculation or water salinity levels. Dry matter yield of shoots was gradually increased with increasing water salinity levels. This phenomenon was more pronounced with $3 \mathrm{dS} \mathrm{m}^{-1}$ rather than $6 \mathrm{dS} \mathrm{m}^{-1}$ water salinity level. This holds true with all inoculation treatments. Similar trend was noticed with root dry matter yield but only in case of uninoculated treatment while the other inoculants reflected decline trend with increasing water salinity levels up to $6 \mathrm{dS} \mathrm{m}^{-1}$. High values of root dry matter yield were recorded under fresh water when the plants inoculated with Azospirillum either individually or in combination with Rhizobium. In this regard, the shoot dry matter, under $3 \mathrm{dSm}^{-1}$ water salinity level, was relatively increased by about $10.6 \%, 40.5 \%, 12.5 \%$ and $7.9 \%$ over fresh water, for uninoculated, Azospirillum, Rhizobium and dual inoculants, respectively. Under $6 \mathrm{dS} \mathrm{m}-1$ level these relative increments were $10.6 \%$, $29.1 \%, 3.4 \%$ and $-1.1 \%$ for the same sequence. Regarding the root dry matter yield, under inoculation treatments, reduction was induced by increasing water salinity levels up to 3 and $6 \mathrm{dS} \mathrm{m}^{-1}$. Reduction was about $24.7 \%, 11.7 \%$ and $6.8 \%, 14.3 \%$ for Azospirillum and $\mathrm{Az}+\mathrm{Rh}$ under 3 and 6 $\mathrm{dS} \mathrm{m}{ }^{-1}$, respectively. Variation in root dry matter as affected by water salinity levels under Rhizobium inoculation was negligible. These results are in harmony with those obtained by Ali (2003) who found that the dry weight of lupin shoots and seeds were slightly increased at $3 \mathrm{dS} \mathrm{m}^{-1}$ water salinity level comparable to fresh water treatment while roots were decreased with the same level and up to $9 \mathrm{dS} \mathrm{\textrm {m } ^ { - 1 }}$ levels. Also, he found that the growth parameters of plants inoculated with salt-tolerant strains of Rhizobium were better than those inoculated with normal one. Reduction of plant growth and dry-matter accumulation under saline conditions has been found in several important grain legumes (Delgado et al., 1994). On the same line, Tejera et al., (2006) reported that the parameters of growth and nitrogen fixation were affected under salt stress in all chickpea cultivars tested; plant dry weight decreased by about 15\% in ILC1919; and in Sirio and Lechoso about 50\% with the highest salt dosage $(100 \mathrm{mM} \mathrm{NaCl})$. ILC1919 showed a less growth accompanied by a lower dry matter formation under low salt conditions compared with most of the salt sensitive cultivar. Nitrogenase activity decreased by about $60 \%$ in the salt-resistant cultivar (cv. ILC1919) and more than $90 \%$ in salt-sensitive cultivars (cv. Sirio and Lechoso) with the highest salt dosage during the reproductive growth. 
Table 3. Effect of irrigation water salinity and bacterial inoculation on dry matter yield $\left(\mathrm{g} \mathrm{pot}^{-1}\right)$ of shoot and root of lupin plants

\begin{tabular}{|c|c|c|c|c|c|c|}
\hline \multirow{3}{*}{$\begin{array}{c}\text { Inoculation } \\
\text { treatment }\end{array}$} & \multicolumn{3}{|c|}{ Shoot } & \multicolumn{3}{|c|}{ Root } \\
\hline & \multicolumn{6}{|c|}{ Irrigation water salinity $\mathbf{d S ~}^{-1}$} \\
\hline & F. water & 3 & 6 & F. water & 3 & 6 \\
\hline Uninoc & 8.5 & 9.4 & 9.4 & 3.8 & 7.3 & 5.5 \\
\hline $\mathrm{Az}$ & 7.9 & 11.1 & 10.2 & 7.3 & 5.5 & 6.8 \\
\hline $\mathrm{Rh}$ & 8.8 & 9.9 & 9.1 & 5.4 & 5.4 & 5.1 \\
\hline$A z+R h$ & 8.9 & 9.6 & 8.8 & 7.7 & 6.8 & 6.6 \\
\hline LSD 0.05 & & & & & & \\
\hline Inoculation & & & & & & \\
\hline Salinity & & & & & & \\
\hline I $\times S$ & & & & & & \\
\hline
\end{tabular}

Means in the same column followed by the same letter are not significantly different at $P \leq$ 0.05

Growth response to $\mathrm{NaCl}$ treatment varied with the common bean genotypes, as shown by shoot and root dry weights. The growth of plants of the five cultivars tested was very much affected by salinity at $25 \mathrm{mM}$, where an important and significant shoot and root dry weight decrease was noticed $(p<0: 05)$. Maximal reductions in shoot and root dry weights caused by $25 \mathrm{mM}$ of salinity were respectively $69 \%$ and $71 \%$, registered for Coco Blanc (Bouhmouch et al. 2005).

Concerning the effect of bacterial inoculation, the dry weight of shoots and roots was significantly affected under different water salinity levels. Shoot dry matter was decreased with individual Azospirillum but increased with individual Rhizobium and dual inoculum when plants were irrigated with fresh water. Under $3 \mathrm{dS} \mathrm{m}^{-1}$ water salinity level, all inoculation treatments induced an increase of shoot dry weight as compared to the uninoculated control. With $6 \mathrm{dS} \mathrm{m}^{-1}$, only Azospirillum inocula induced increase in shoot dry weight while a slight reduction was indicated with Rhizobium either alone or in combination with Azospirillum. Another view was noticed with root dry weight where it increased by inoculation, in general, when irrigation with fresh water taken place. In this respect, the highest value was recorded with dual inoculum followed by Azospirillum then Rhizobium. It accounts for more than one fold, $92 \%$ and $42 \%$ over the uninoculated treatment for dual inoculum, Azospirillum and Rhizobium, respectively. Application of $3 \mathrm{dS} \mathrm{m}^{-1}$ water salinity level showed a reduction in root dry weight as affected by inoculation treatments. Reduction was more pronounced with individual inoculants than dual one. Under $6 \mathrm{dS} \mathrm{m}^{-1}$ water salinity level, the trend was fluctuated where the root dry matter yield was increased over the uninoculated control with Azospirillum alone and dual inoculum while it slightly decreased with Rhizobium. In general, our results are partially agree with Bashan et al. (1990) who stated that all growth parameters measured for soybean were significantly higher for $A$. brasilense-inoculated plants than for noninoculated plants, regardless of the bacterial strain. Similarly, Molla et al. (2001) reported that the treatment of clipped soybean roots with $A$. brasilense $\mathrm{Sp} 7$ caused a $63 \%$ increase in root dry weight, but more than a 6 -fold increase in specific 
root length (root length per unit root dry weight), and more than a 10-fold increase in total root length.

Vessey (2003) reviewed evidence for a number of modes of action for PGPR stimulation of legume-rhizobia symbioses, but the most commonly implicated mode is phytohormone-induced (usually IAA) stimulations of root growth (e.g., Molla et al., 2001; Srinivasan et al., 1996; Vessey and Buss, 2002). In this way, the stimulation of nodulation is most commonly an indirect effect; the PGPR stimulates root growth, which provides more sites for infection and nodulation. However, this is not always the case. Cattelan et al. (1999) found that a number of putative PGPR had positive effects on shoot and/or root growth in soybean and were positive for production of IAA or ACC deaminase, but these putative PGPR had no positive effects on nodulation. In fact, Cattelan et al. (1999) found several rhizospheric isolates which stimulated aspects of the soybean-bradyrhizobia symbiosis and which had $\hat{a}-$ glucoanase or cyanide production (if these substances were involved or how they might stimulate the soybean-bradyrhizobia symbiosis is unclear). Some PGPR that stimulate legume-rhizobia symbioses appear to more directly influence the development of the symbioses. Burdman et al. (1996) related Azospirillum brasilense-mediated stimulation in nodulation of common bean to an increased production of flavonoids by the legume host.

\section{Nitrogen uptake}

Nitrogen uptake by shoot and root of lupin was presented in Table (4). It seems that the $\mathrm{N}$ uptake by shoots was positively affected by water salinity levels under bacterial inoculation except the dual treatments where $\mathrm{N}$ uptake tended to decrease with increasing water salinity levels. Relatively, results showed the following orders:

Uninoculated: $6 \mathrm{dS} \mathrm{m}^{-1}(33 \%)>3 \mathrm{dS} \mathrm{m}^{-1}(10.4 \%)>$ Fresh water

Azospirillum: $6 \mathrm{dS} \mathrm{m}^{-1}(113 \%)>3 \mathrm{dS} \mathrm{m}^{-1}(89 \%)>$ Fresh water

Rhizobium: $\quad 3 \mathrm{dS} \mathrm{m}^{-1}(1.5 \%)>$ Fresh water $>6 \mathrm{dS} \mathrm{m}^{-1}(-19 \%)$

$\mathrm{Az}+\mathrm{Rh}: \quad$ Fresh water $>6 \mathrm{dS} \mathrm{m}^{-1}(-2.7 \%)>3 \mathrm{dS} \mathrm{m} \mathrm{m}^{-1}(-8.2 \%)$

These trends reflected that lupin plants grew well under uninoculated treatment, inoculation with Azospirillum and to somewhat extent with Rhizobium but negatively affected when the dual inoculation was concerned. Despite of that, the reduction in nitrogen uptake by shoots was non significant and could be neglected. Concerning roots, $\mathrm{N}$ uptake, in general, tended to decrease with increasing water salinity levels up to $6 \mathrm{dS} \mathrm{m}^{-1}$ under all inoculation treatments. In this respect, the interaction between water salinity and bacterial inoculation revealed the following orders:

Uninoculated: $3 \mathrm{dS} \mathrm{m}^{-1}(40.5 \%)>6 \mathrm{dS} \mathrm{m}^{-1}(33 \%)>$ Fresh water

Azospirillum: Fresh water $>3 \mathrm{dS} \mathrm{m}^{-1}(-25.6 \%)>6 \mathrm{dS} \mathrm{m}^{-1}(-33.5 \%)$

Rhizobium: Fresh water $>3 \mathrm{dS} \mathrm{m}^{-1}(-16.6 \%)>6 \mathrm{dS} \mathrm{m}^{-1}(-28.6 \%)$

$\mathrm{Az}+\mathrm{Rh}: \quad$ Fresh water $>3 \mathrm{dS} \mathrm{m}^{-1}(-39.5 \%)>6 \mathrm{dS} \mathrm{m}^{-1}(-42 \%)$

This indicates, except the uninoculated treatment, that $\mathrm{N}$ uptake by roots was severely affected by increasing water salinity levels as compared to fresh water treatment.

Bacterial inoculation, in most cases, reflected enhancement of $\mathrm{N}$ uptake by shoots under different water salinity levels as compared to the 
uninoculated treatment. With exception of fresh water treatment, Azospirillum inoculation cause increments in $\mathrm{N}$ uptake under both 3 and $6 \mathrm{dS} \mathrm{m} \mathrm{m}^{-1}$ salinity levels. In this respect, the relative increments were $28.8 \%$ and $20.3 \%$ for $3 \mathrm{dS}$ $\mathrm{m}^{-1}$ and $6 \mathrm{dS} \mathrm{m}^{-1}$ water salinity levels, respectively. In case of Rhizobium alone or in combination with Azospirillum, increase of $\mathrm{N}$ uptake by shoots was only recorded with fresh water and $3 \mathrm{dS} \mathrm{m}^{-1}$ treatments, but a little bit

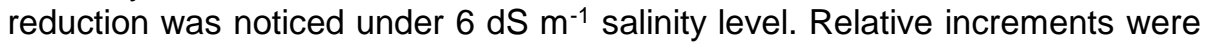
account for $36.8 \%$ and $25.8 \% ; 26.1 \%$ and $4.9 \%$ under fresh water and 3 dS $\mathrm{m}^{-1}$ for Rhizobium and Rhizobium plus Azospirillum, respectively. On the other hand, the relative reductions induced under $6 \mathrm{dS} \mathrm{m}^{-1}$ salinity level were $-16.6 \%$ and $-7.7 \%$ for the same sequence of bacterial inoculants. Nitrogen uptake by roots was dramatically affected by inoculation.

Table 4. Effect of irrigation water salinity and bacterial inoculation on $\mathbf{N}$ uptake $\left(\mathrm{mg} \mathrm{pot}^{-1}\right)$ by shoot and root of lupin plants

\begin{tabular}{|c|c|c|c|c|c|c|}
\hline \multirow{3}{*}{$\begin{array}{c}\text { Inoculation } \\
\text { treatment }\end{array}$} & \multicolumn{3}{|c|}{ Shoot } & \multicolumn{3}{|c|}{ Root } \\
\hline & \multicolumn{6}{|c|}{ Irrigation water salinity $\mathbf{d S}^{\mathbf{m}^{-1}}$} \\
\hline & F. water & 3 & 6 & F. water & 3 & 6 \\
\hline Uninoc & $7.23 \mathrm{CD}$ & $7.98 \mathrm{BCD}$ & $9.61 \mathrm{ABC}$ & $2.94 \mathrm{C}$ & $4.13 \mathrm{ABC}$ & $3.68 \mathrm{ABC}$ \\
\hline $\mathrm{Az}$ & $5.43 \mathrm{D}$ & $10.28 \mathrm{AB}$ & $11.56 \mathrm{~A}$ & $4.96 \mathrm{AB}$ & $3.69 \mathrm{ABC}$ & $3.30 \mathrm{ABC}$ \\
\hline $\mathrm{Rh}$ & $9.89 \mathrm{ABC}$ & $10.04 \mathrm{AB}$ & $8.01 \mathrm{BCD}$ & $4.34 \mathrm{ABC}$ & $3.62 \mathrm{ABC}$ & $3.10 \mathrm{C}$ \\
\hline$A z+R h$ & $9.12 \mathrm{ABC}$ & $8.37 \mathrm{BCD}$ & $8.87 \mathrm{ABC}$ & $5.19 \mathrm{~A}$ & $3.14 \mathrm{BC}$ & $3.01 \mathrm{C}$ \\
\hline \multicolumn{7}{|l|}{ LSD 0.05} \\
\hline $\begin{array}{l}\text { Inoculation } \\
\text { Salinity } \\
\text { I x S }\end{array}$ & & $\begin{array}{l}1.957 \\
2.292 \\
2.606\end{array}$ & & & $\begin{array}{l}1.333 \\
1.560 \\
1.775\end{array}$ & \\
\hline
\end{tabular}

Means in the same column followed by the same letter are not significantly different at $P \leq$ 0.05

It was only increased by inoculation when plants were irrigated with fresh water. Under both 3 and $6 \mathrm{dS} \mathrm{m}^{-1}$ salinity levels, slight decrease was noticed with inoculation comparing to uninoculated treatment. Relative increments in root- $\mathrm{N}$, under fresh water, as affected by bacterial inoculation could be as following:

Azospirillum+Rhizobium > (76.5\%) Azospirillum (68.7\%) > Rhizobium $(47.6 \%)$

Opposite direction was recorded with 3 and $6 \mathrm{dS} \mathrm{m}-1$ water salinity levels where the root- $\mathrm{N}$ tended to decrease with inoculation. Decreases followed the next trends:

Under $3 \mathrm{dS} \mathrm{m}^{-1}$ :

Azospirillum (-10.7\%) > Rhizobium (-12.3\%) > Azospirillum + Rhizobium $(-24 \%)$

Under $6 \mathrm{dS} \mathrm{m}^{-1}$ :

Azospirillum (-10.3\%) > Rhizobium (-15.8\%) > Azospirillum + Rhizobium $(-18.2 \%)$

These results indicted that the bacterial inoculants were negatively affected by salinity stress of irrigation water. 
In accordance, Tilak et al. (2006) stated that the Rhizobium strain AR-2$2 \mathrm{k}$ interacted differentially with PGPR isolates and showed significant variations in nodulation, $\mathrm{N}_{2}$ fixation and total $\mathrm{N}$ content in shoots of pigeonpea. Co-inoculation of all cultures of PGPR produced more nodules, a greater dry weight of nodules and more $\mathrm{N}$ in shoots than a single inoculation with Rhizobium strain AR-2-2 k and uninoculated control plants. Also, he added that the $\mathrm{N}$ in shoots increased by $15.2,8.5$ and $14.3 \%$ after combined inoculation of seed with Rhizobium and Pseudomonas putida, P. fluorescens and Bacillus cereus, respectively, compared with Rhizobium inoculation alone.

Despite the lack of evidence indicating that $\mathrm{N}$ applied to saline soils or media above a level considered optimal under non-saline conditions improves plant growth or yield (Grattan and Grieve 1999), a number of laboratory and greenhouse studies have shown that salinity can reduce $\mathrm{N}$ accumulation in plants (Pessarakli, 1991; Al-Rawahy et al., 1992). This is not

In a greenhouse experiment conducted by Mer et al. (2000) on four crop plants in the western region of Gujarat State India to assess their responses to increasing levels of soil salinity. Of the four crop plants tested (Hordeum vulgare, barley; Triticum aestivum, wheat; Cicer arietinum, gram and Brassica juncea, mustard), barley appeared to be the most tolerant to salinity with regard to seed germination and early growth of the plants. Wheat; gram and mustard were tolerant only to low soil salinity. However, high salt concentrations in the soil reduced the absorption of nitrogen and phosphorus by the young plants. The imbalance of mineral nutrients resulted in a reduction or an inhibition of plant growth. High salinity also caused burning symptoms on the leaves and shoot apices of barley.

\section{Potassium uptake by shoot and root}

As shown in Table (5), the acquisition of $K$ by shoot and roots of lupin plants was frequently affected by either water salinity or bacterial inoculation. Potassium in shoots tended to increase with increasing water salinity levels up to $6 \mathrm{dS} \mathrm{m}^{-1}$. This holds true with different inoculants including the uninoculated treatment. It is worthy to mention that the highest values of potassium accumulated in shoots as affected by water salinity were recorded with Rhizobium inoculation while the lowest were under uninoculated treatment. Ascending order of $\mathrm{K}$ accumulation in shoots with increasing water salinity could be arranged as following:

Uninoculated: $6 \mathrm{dS} \mathrm{m}^{-1}>3 \mathrm{dS} \mathrm{m}^{-1}>$ Fresh water

Azospirillum: $3 \mathrm{dS} \mathrm{m}^{-1}>6 \mathrm{dS} \mathrm{m}^{-1}>$ Fresh water

Rhizobium: $\quad 3 \mathrm{dS} \mathrm{m}^{-1}>6 \mathrm{dS} \mathrm{m}^{-1}>$ Fresh water

$\mathrm{Az}+\mathrm{Rh}: \quad 6 \mathrm{dS} \mathrm{m}^{-1}>3 \mathrm{dS} \mathrm{m}^{-1}>$ Fresh water

Another view was recorded with root-K, where it increased with increasing water salinity level only with dual inoculation $(A z+R h)$. Reversible trend was noticed with the rest of inoculation treatments where it declines with increasing water salinity levels up to $6 \mathrm{dS} \mathrm{m}^{-1}$. In this regard, the highest reduction in absorbed $\mathrm{K}$ was recorded with $6 \mathrm{dS} \mathrm{m}^{-1}$ under the uninoculated treatment $\left(58.3 \mathrm{mg} \mathrm{pot}^{-1}\right)$. While the highest increment in root- $\mathrm{K}$ was noticed 
also with $6 \mathrm{dS} \mathrm{m}^{-1}$ but under dual inoculation of Azospirillum plus Rhizobium (74.3 $\mathrm{mg} \mathrm{pot}^{-1}$ ).

Table 5. Effect of irrigation water salinity and bacterial inoculation on $\mathrm{K}$

\begin{tabular}{|c|c|c|c|c|c|c|}
\hline \multirow{3}{*}{$\begin{array}{c}\text { Inoculation } \\
\text { treatment }\end{array}$} & \multicolumn{3}{|c|}{ Shoot } & \multicolumn{3}{|c|}{ Root } \\
\hline & \multicolumn{6}{|c|}{ Irrigation water salinity dS $\mathbf{~ m}^{-1}$} \\
\hline & F. water & 3 & 6 & F. water & 3 & 6 \\
\hline Uninoc & $33.7 \mathrm{C}$ & $34.0 \mathrm{C}$ & $40.3 \mathrm{ABC}$ & $78.7 \mathrm{~A}$ & $69.7 \mathrm{~A}$ & $58.3 \mathrm{~A}$ \\
\hline $\mathrm{Az}$ & $34.0 \mathrm{C}$ & $43.7 \mathrm{ABC}$ & $38.7 \mathrm{BC}$ & $74.7 \mathrm{~A}$ & $63.3 \mathrm{~A}$ & $63.3 \mathrm{~A}$ \\
\hline $\mathrm{Rh}$ & $42.0 \mathrm{ABC}$ & $52.7 \mathrm{~A}$ & $52.3 \mathrm{AB}$ & $71.0 \mathrm{~A}$ & $65.3 \mathrm{~A}$ & $67.0 \mathrm{~A}$ \\
\hline$-A z+R h$ & $40.3 \mathrm{ABC}$ & $45.3 \mathrm{ABC}$ & $47.0 \mathrm{ABC}$ & $59.7 \mathrm{~A}$ & $61.7 \mathrm{~A}$ & $74.3 \mathrm{~A}$ \\
\hline \multicolumn{7}{|l|}{ LSD 0.05} \\
\hline Inoculation & \multirow{3}{*}{\multicolumn{3}{|c|}{$\begin{array}{l}9.834 \\
11.51 \\
13.10\end{array}$}} & \multirow{3}{*}{\multicolumn{3}{|c|}{$\begin{array}{l}21.90 \\
25.64 \\
29.16 \\
\end{array}$}} \\
\hline Salinity & & & & & & \\
\hline $\mathrm{IXS}$ & & & & & & \\
\hline
\end{tabular}

Means in the same column followed by the same letter are not significantly different at $P \leq$ 0.05

Concerning the effect of bacterial inoculation, in general, the values of $\mathrm{K}$ uptake by shoots was increased due to inoculation treatments. In this regard, the best values were recorded with individual Rhizobium followed by dual inoculum then the Azospirillum. This holds true under all water salinity levels. Opposite direction was noticed with root-K where it decreased with inoculation treatments comparable to uninoculated one. This holds true under fresh water and $3 \mathrm{dS} \mathrm{m}^{-1}$ water salinity levels, but with $6 \mathrm{dS} \mathrm{m}^{-1}$ level the absorption of $\mathrm{K}$ by roots was increased due to different inoculation treatments. Under this level, the best value of $\mathrm{K}$ uptake was recorded with dual inocula followed by Rhizobium, the Azospirillum. Relative increments in this case were accounted for $27.4 \%, 14.9 \%$ and $8.6 \%$ over the uninoculated control for dual inoculum, Rhizobium and Azospirillum, respectively.

\section{Sodium uptake by shoot and root}

Data presented in Table (6) showed that $\mathrm{Na}$ uptake by shoot and root was positively affected by either increasing water salinity levels or bacterial inoculation. It is obvious that $\mathrm{Na}$ absorption was gradually increased with increasing water salinity levels up to $6 \mathrm{dS} \mathrm{m}^{-1}$. This holds true under all inoculation treatments. Also, the results of both shoots and roots were nearly closed to each other. Generally, the highest values of Na content in shoots or roots were recorded with $6 \mathrm{dS} \mathrm{m}^{-1}$ water salinity level.

Bacterial inoculation reflected, in general, increase in $\mathrm{Na}$ uptake by shoots (F.W. and $3 \mathrm{dS} \mathrm{m}^{-1}$ ) or roots (F.W. and $6 \mathrm{dS} \mathrm{m}^{-1}$ ) especially in case of dual inoculation treatment where the highest values were recorded. Relatively, it accounts for $9.7 \%, 14 \%$ and $-06 \% ; 40.3 \%,-0.5 \%$ and $21.2 \%$ for fresh water, $3 \mathrm{dS} \mathrm{m-1}$ and $6 \mathrm{dS} \mathrm{m}-1$ under shoots and roots, respectively. Sometimes, the interaction between water salinity levels and inoculation treatments reflected fluctuated trends in sodium uptake by either shoots or roots. 
The salinity sensitivity of soybean cultivars was studied to determine the effect of salinity on seed germination, shoot and root dry weights, and leaf mineral contents (Essa 2002). He added that salinity stress induced a significant increase in leaf sodium $\left(\mathrm{Na}^{+}\right)$and chloride $(\mathrm{Cl})$ in all cultivars. However, the cultivar Lee maintained lower $\mathrm{Na}^{+}$and $\mathrm{Cl}^{-}$concentrations, a higher potassium $\left(\mathrm{K}^{+}\right)$concentration and a higher $\mathrm{K}^{+} / \mathrm{Na}^{+}$ratio at higher salinity levels than Coquitt and Clark 63. Saline stress reduced the accumulation of $\mathrm{K}^{+}$, calcium $\left(\mathrm{Ca}^{2+}\right)$ and magnesium $\left(\mathrm{Mg}^{2+}\right)$ in the leaves of the cultivars studied.

Table 6. Effect of irrigation water salinity and bacterial inoculation on $\mathrm{Na}$ uptake $\left(\mathrm{mg} \mathrm{pot}^{-1}\right)$ by shoot and root of lupin plants

\begin{tabular}{|c|c|c|c|c|c|c|}
\hline \multirow{3}{*}{$\begin{array}{c}\text { Inoculation } \\
\text { treatment }\end{array}$} & \multicolumn{3}{|c|}{ Shoot } & \multicolumn{3}{|c|}{ Root } \\
\hline & \multicolumn{6}{|c|}{ Irrigation water salinity $\mathbf{d S} \mathbf{~ m}^{-1}$} \\
\hline & F. water & 3 & 6 & F. water & 3 & 6 \\
\hline Uninoc & $62.0 \mathrm{C}$ & $74.3 \mathrm{BC}$ & $97.3 \mathrm{~A}$ & $66.3 \mathrm{BC}$ & $79.7 \mathrm{ABC}$ & $83.3 \mathrm{ABC}$ \\
\hline $\mathrm{Az}$ & $62.0 \mathrm{C}$ & $81.3 \mathrm{AB}$ & $92.0 \mathrm{~A}$ & $63.7 \mathrm{BC}$ & $76.0 \mathrm{ABC}$ & $90.3 \mathrm{ABC}$ \\
\hline $\mathrm{Rh}$ & $60.7 \mathrm{C}$ & $94.0 \mathrm{~A}$ & $96.0 \mathrm{~A}$ & $61.7 \mathrm{C}$ & $86.0 \mathrm{ABC}$ & $99.3 \mathrm{~A}$ \\
\hline$A z+R h$ & $68.0 \mathrm{C}$ & $84.7 \mathrm{AB}$ & $96.7 \mathrm{~A}$ & $93.0 \mathrm{AB}$ & $79.3 \mathrm{ABC}$ & $101.0 \mathrm{~A}$ \\
\hline \multicolumn{7}{|l|}{ LSD 0.05} \\
\hline Inoculation & \multirow{3}{*}{\multicolumn{3}{|c|}{$\begin{array}{l}11.36 \\
13.30 \\
15.13\end{array}$}} & \multirow{3}{*}{\multicolumn{3}{|c|}{$\begin{array}{l}20.94 \\
24.52 \\
27.89\end{array}$}} \\
\hline Salinity & & & & & & \\
\hline IXS & & & & & & \\
\hline
\end{tabular}

Means in the same column followed by the same letter are not significantly different at $P \leq$ 0.05

Numerous studies with a wide variety of horticultural crops have shown that $\mathrm{K}^{+}$concentration in plant tissue, expressed on a dry mass basis, declines as the Na-salinity or as the $\mathrm{Na}^{+} / \mathrm{Ca}^{2+}$ in the root media is increased (e.g. Graifenberg et al., 1995; Perez-Alfocea et al., 1996). In contrast, other research has demonstrated that $\mathrm{K}^{+}$may be preferentially acquired and transported against a strong $\mathrm{Na}^{+}$concentration gradient. As a result, $\mathrm{K}^{+}$levels in the cell sap of bean leaves increased with increasing $\mathrm{NaCl}$-salinity (Cachorro et al., 1993). Often, however, leaf- $\mathrm{Na}^{+}$accumulation increases in concert with leaf- $\mathrm{K}^{+}$and both $\mathrm{K}^{+} / \mathrm{Na}^{+}$ratio and $\mathrm{K}^{+}: \mathrm{Na}^{+}$selectivity coefficient decrease with increases in salinity (Akhavan-Kharazian et al., 1991; Cachorro et al., 1993).

The effective role of Azospirillum inocula on growth and nutrient uptake when accompanied with other microorganisms has excellently reviewed by Bashan et al. (2004). The most notable phenomenon in Azospirillum inoculation, as in the early 1990s (Bashan and Holguin 1997a, b), is that inoculation is more successful and more profitable when other microorganisms are co-inoculated with Azospirillum. Inoculation consortia apparently work better when phosphate-solubilizing bacteria, Azotobacter, rhizobia, bacilli, and VAM fungi are incorporated, perhaps aiding the growth of each other by synergistically providing nutrients, removing inhibitory products, and in the process, enhancing plants' ability to grow better. Although most mechanisms by which co-inoculation affects plant growth are as yet unknown, apparently co-inoculation allows plants to achieve a more 
balanced nutrition and (or) absorption of nutrients is improved. The most notable phenomena reported are increased mineral uptake, reduction in the use of $\mathrm{N}$ and $\mathrm{P}$ fertilizers by $25 \%-50 \%$, increases in available NPK from soil, enhanced quality characteristics of the yield, higher net return, and better cost-benefit ratio. In many inoculation tests, especially in developing countries, it appeared that co-inoculation was the method of choice in the last decade. With better characterization of the strains and better inoculant carriers, it might be the preferred future mode of application for Azospirillum at the field level.

\section{REFERENCES}

Akhavan-Kharazian, M., Campbell, W.F., Jurinak, J.J., Dudley, L.M., 1991. Calcium amelioration of $\mathrm{NaCl}$ effects on plant growth, chlorophyll, and ion concentration in Phaseolus vulgaris. Arid Soil Res. Rehab. 5, 9-19.

Ali M.M. (2003) Response of lupine plants to the Rhizobium inoculation under drip irrigation with saline water, using ${ }^{15} \mathrm{~N}$ isotope dilution. M. Sc. Thesis, IAM-Bari, Italy.

Al-Rawahy, S.A., Stroehlein, J.L., Pessarakli, M., 1992. Dry matter yield and nitrogen-15, $\mathrm{Na}^{+}, \mathrm{Cl}^{-}$and $\mathrm{K}^{+}$content of tomatoes under sodium chloride stress. J. Plant Nutr. 15, 341-358.

Ayers, R.S; Westcott, D.W. (1989). Water Quality for Agriculture, FAO, irrigation and drainage paper No. 29: p. 1-29

Bashan Y., Holguin G., and de-Bashan L. E. (2004) Azospirillum-plant relationships: physiological, molecular, agricultural, and environmental advances (1997-2003). Can. J. Microbiol. 50, 521-577.

Bashan, Y., and Holguin, G. 1997a. Azospirillum-plant relationships: environmental and physiological advances (1990-1996). Can. J. Microbiol. 43: 103-121.

Bashan, Y., and Holguin, G. 1997b. Short- and medium term avenues for Azospirillum inoculation. In Plant growth-promoting rhizobacteria-present status and future prospects. Edited by A. Ogoshi, K. Kobayashi, Y. Homma, F. Kodama, N. Kondo, and S. Akino. Faculty of Agriculture, Hokkaido University, Sapporo, Japan. pp. 130-149.

Bashan, Y., Harrison, S.K. and Whitmoyer, R.E. (1990) Enhanced Growth of Wheat and Soybean Plants Inoculated with Azospirillum brasilense Is Not Necessarily Due to General Enhancement of Mineral Uptake. Appl. Environ. Microbiol. 56: 769-775.

Bouhmouch I., Souad-Mouhsine B., Brhada F., Aurag J. (2005) Influence of host cultivars and Rhizobium species on the growth and symbiotic performance of Phaseolus vulgaris under salt stress. J. Plant Physiology 162, 1103-1113.

Burdman S, Volpin H, Kapulnik $Y$ and Okon $Y 1996$ Promotion of nod gene inducers and nodulation in common bean (Phaseolus vulgaris) root inoculated with Azospirillum brasilense Cd. Appl. Environ. Microbiol. 62, 3030-3033.

Cachorro, P., Ortiz, A., Cerda, A., 1993. Growth, water relations and solute composition of Phaseolus vulgaris L. under saline conditions. Plant Sci. 95, 23-29. 
Cattelan A J, Hartel P G and Fuhrmann J J 1999 Screening for plant growthpromoting rhizobacteria to promote early soybean growth. Soil Sci. Soc. Am. J. 63, 1670-1680.

Delgado, M.J., Ligero, F., and Lluch, C., (1994). Effects of salt stress on growth and nitrogen fixation by pea, faba-bean, common bean and soybean plants. Soil Biol. Biochem. 26: 371-376.

Dobereiner, $\mathrm{J}$ and Day, JM (1976) Associative symbiosis in tropical grasses: Characterization of microorganisms and dinitrogen fixing sites. In: Proceedings of the $1^{\text {st }}$ International Symposium on Nitrogen Fixation. Newton, Nyman (eds.), Pullman, Washington pp. 518-538.

Essa T. A. (2002) Effect of salinity stress on growth and nutrient composition of three soybean (Glycine max L. Merrill) cultivars. J. Agronomy \& Crop Science 188, 86-93.

Galal YGM (1997) Dual inoculation with strains of Bradyrhizobium japonicum and Azospirillum brasilense to improve growth and biological nitrogen fixation of soybean (Glycine max L.). Biol Fertil Soils 24: 317-322

Galal, YGM and Ali, BE (2004) Biofertilization and organic farming approaches. Special Issue of Egypt. J. Agric. Res., vol. 5 (1): 99-176.

Grattan S.R. and Grieve C.M. (1999) Salinity-mineral nutrient relations in horticultural crops. Scientia Horticulturae 78, 127-157.

Graifenberg, A., Giustiniani, L., Temperini, O., Lipucci di Paola, M., 1995. Allocation of $\mathrm{Na}, \mathrm{Cl}, \mathrm{K}$ and $\mathrm{Ca}$ within plant tissues in globe artichoke (Cynara scolimus L.) under saline-sodic conditions. Sci. Hort. 63, 1-10.

Hamdy, A. 2005. Evidence of the Potential Use of Saline Water in Irrigation as Freshwater Saving Practice. In : Non-Conventional Water Resources: Salinity and Saline Irrigation Practices and Management. The 3rd Workshop of WASAMED - Thematic Network Non-Conventional Water Use, Cairo, EGYPT, p. 1-42.

Hamdy A. (2005) Soil, Water and Plant Analysis Manual for Arid and Semi Arid Countries of the Mediterranean. CIHEAM, IAM-Bari, Italy.

Howieson, J. G., Reeven, N. and Yates R. (1994) The selection of effective inoculant Bradyrhizobium sp. lupinus. for new lupin and serradella species. Proc. First Australian Lupin Technical Symp. Dracup and palta, eds. Pp. 270-273.

Kant, S. \& Kafkafi, U. 2002. Potassium and abiotic stresses in plants. In N.S. Pasricha \& S.K. Bansal, eds. Potassium for sustainable crop production, pp. 233-251. Gurgaon, India, Potash Research Institute of India and International Potash Institute.

Mer R. K., Prajith P. K., Pandya D. H. and Pandey A. N. (2000) Effect of salts on germination of seeds and growth of young plants of Hordeum Vulgare, Triticum aestivum, Cicer arietinum and Brassica juncea. J. Agronomy \& Crop Science 185, 209-217.

Molla A H, Shamsuddin Z H, Halimi M S, Morziah M and Puteh A B 2001 Potential for enhancement of root growth and nodulation of soybean coinoculated with Azospirillum and Bradyrhizobium in laboratory systems. Soil Biol. Biochem. 33, 457-463. 
Page , A.L.; Miller, R. H. and Keeney, D.R. (eds), (1982). Methods of Soil Analysis. II. Chemical and Microbiological properties. $2^{\text {nd }}$ edn. ASA. SSSA, Madison, WI, USA.

Patra A. K., Le Roux X., Abbadie L., Clays-Josserand A., Poly F., Loiseau P., and Louault F. (2006) Effect of microbial activity and nitrogen mineralization on free-living nitrogen fixation in permanent grassland soils. J. Agronomy \& Crop Science (doi:10.1111/j.1439037X.2006.00247.X)

Perez-Alfocea, F., Balibrea, M.E., Santa Cruz, A., Estan , M.T., 1996. Agronomical and physiological characterization of salinity tolerance in a commercial tomato hybrid. Plant Soil 180, 251-257.

Pessarakli, M., 1991. Dry matter yield, nitrogen-15 absorption, and water uptake by green bean under sodium chloride stress. Crop Sci. 31, 16331640.

Rana, R.S. 1986. Breeding crop varieties for salt-affected soils. In: Approaches for incorporating drought and salinity resistance in crop plants, pp. 24-55. New Delhi, Oxford and IBH.

Raza, S., Abdel-Wahed, A., Swelim, D., Jornsgrad, B., Abdel-Wahed, S.M. and Christiansen, J.L. (2000) Effect of single and multi strain Rhizobial inoculations lupine cultivation at newly reclaimed land in Egypt. In: Proc Tenth Microbial. Conf. El-nawawy et al . eds., pp. 59-73

Roy R.N., Finck A., Blair G.J. \& Tandon H.L.S. (eds.) 2006. Plant nutrition for food security $A$ guide for integrated nutrient management Plant nutrition for food security. FAO Fertilizer And Plant Nutrition Bulletin 16, Rome, Italy pp. 348.

Ryan, J., Estefan, G. and Rashid, A. (2001) Soil and Plant Analysis Laboratory Manual, Second Edition, Jointly published by the International Center for Agricultural Research in the Dry Areas (ICARDA) and the National Agricultural Research Center (NARC). Available from ICARDA, Aleppo, Syria. $x+172$ pp. ICARDA, Aleppo, Syria.

Saatovich, S. Z. (2006) Azospirilli of Uzbekistan soils and their influence on growth and development of wheat plants. Plant and Soil, 283:137-145.

SAS Institute 1987. SAS/STATTM Guide for personal computers. Version 6 edition, SAS Institute Inc, Cary, NY

Srinivasan M, Petersen D J and Holl F B 1996 Influence of indoleacetic-acidproducing Bacillus isolates on the nodulation of Phaseolus vulgaris by Rhizobium etli under gnotobiotic conditions. Can. J. Microbiol. 42, 10061014.

Steenhoudt $\mathrm{O}$ and Vanderleyden $\mathrm{J} 2000$ Azospirillum, a free-living nitrogen.xing bacterium closely associated with grasses: genetic, biochemical and ecological aspects. FEMS Microbiology Reviews 24, 487-506.

Tejera , N.A., Soussi, M. and Lluch, C. (2006) Physiological and nutritional indicators of tolerance to salinity in chickpea plants growing under symbiotic conditions. Environmental and Experimental Botany 58: 17-24.

Tilak K. V. B. R., Ranganayaki N. and Manoharachari C. (2006) Synergistic effects of plant-growth promoting rhizobacteria and Rhizobium on nodulation and nitrogen fixation by pigeonpea (Cajanus cajan). European Journal of Soil Science, 57, 67-71. 
Vessey J. K. (2003) Plant growth promoting rhizobacteria as biofertilizers. Plant and Soil 255, 571-586.

Vessey J K and Buss T J 2002 Bacillus cereus UW85 inoculation effects on growth, nodulation, and $\mathrm{N}$ accumulation in grain legumes. Controlledenvironment studies. Can. J. Plant Sci. 82, 282-290.

Vincent, JM (1970) Manual for the practical study of root-nodule bacteria. Blackwell, Oxford.

Vlek, P.L.G. \& Vielhauer, K. 1994. Nutrient management strategies in stressed environments. In S.M. Virmani, J.C. Katyal, H. Eswaran \& I.P. Abrol, eds. Stressed ecosystems and sustainable agriculture, pp. 203229. New Delhi, Oxford and IBH.

Zahran H. H. (1999) Rhizobium-legume symbiosis and nitrogen fixation under severe conditions and in an arid climate. Microbiol Mol Biol Rev 63, :968-989.

تعزيز امتصاص المغذيات بواسطة نبات الترمس الملقح بالبكتيريـا والمروى بالميـاه

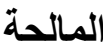

السيد محمود الحديدى1، سليمان محمد سليمان2، يحيى جلال محمد جلال22، محمد عدلي

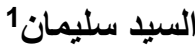

قسم الأراضي، كلية الزراعة، جامعة المنصورة ، 2 قسم بحوث الأراضي والمياه، مركز البحوث النووية، هيئة الطاقة الذرية، أبو زعبل جالزية 13759

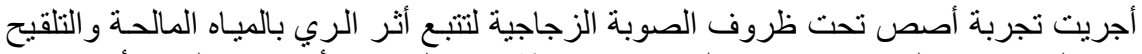

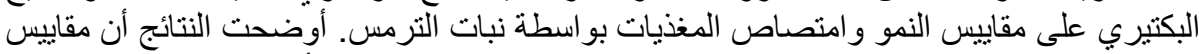

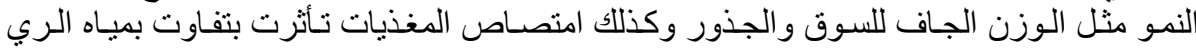

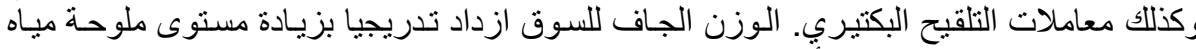

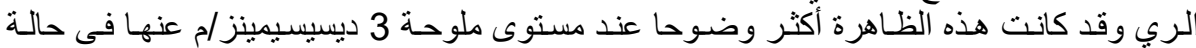

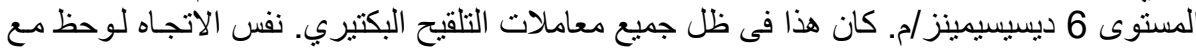

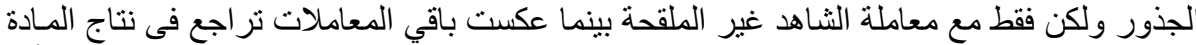

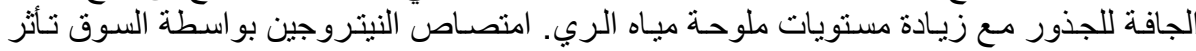

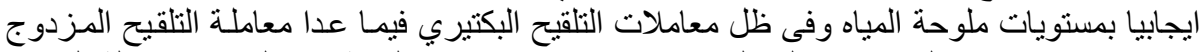

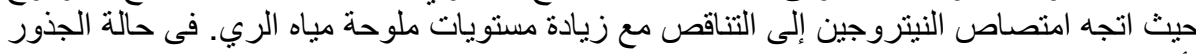

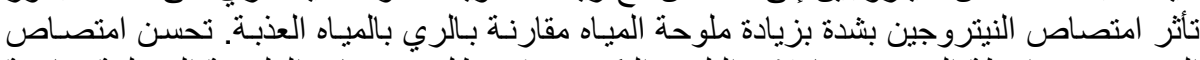

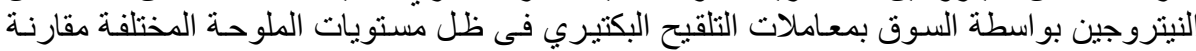

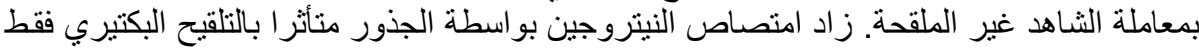

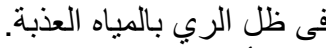

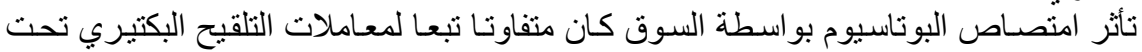

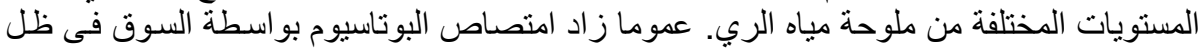

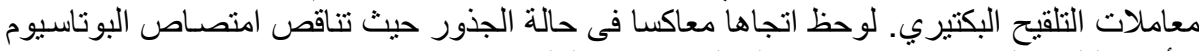
متأثرا بالتلقيح البكتيري مقارنة بمعاملة الثاهد غير الماكير الملقحة.

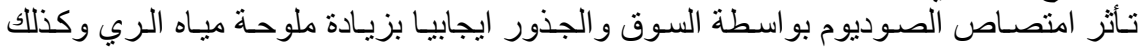

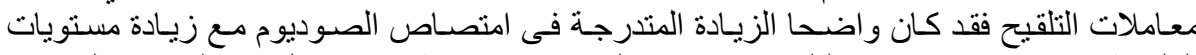

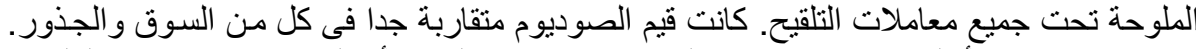

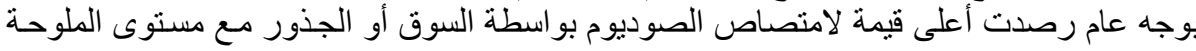
6 
El-Hadidi E. M. et al. 